\title{
The influence of the extraction method on polyphenols, flavonoids composition and anti-hyperlipidemic properties of papaya leaves (Carica papaya Linn.)
}

Sally Abdel-Halim', Magda Ibrahim², Mona Abdel Mohsen ${ }^{1 *}$ (D, Lobna Abou-Setta', Amany Sleem ${ }^{3}$ and Mostafa El-Missiry ${ }^{1}$

\begin{abstract}
Background: Papaya (Carica papaya Linn.) is well known for its nutritional as well as medicinal value. Different parts of the plant including leaves have been used as therapeutic remedies for various diseases. The objective of the present study is to determine the impact of different extraction methods; microwave-assisted, ultrasonic-assisted and conventional maceration on extract yield, polyphenols, flavonoids composition and subsequently, the anti-hyperlipidemic potential of papaya leaves (Carica papaya Linn.).

Results: Innovative extraction methods represented in microwave assisted extraction (MAE) and ultrasonic assisted extraction (UAE) have significant impact on the extract yield and total phenolic and flavonoids content than conventional maceration extraction (CME) of the prepared aqueous ethanol extracts. HPLC assay showed the highest content of bioactive polyphenols characterized extract from the MAE $(29.99 \mathrm{mg} / \mathrm{g})$, followed by UAE $(24.75 \mathrm{mg} / \mathrm{g})$ and the lowest content was that obtained from CME. The aqueous ethanol extract of the leaves obtained by MAE induced significant hypolipidemic activity $(P<0.05)$ in hyperlipidemic rats particularly, the oral treatment with $200 \mathrm{mg} / \mathrm{kg}$ b.wt. which retained the lipid profile to be compatible to the results of rats receiving simvastatin $(0.18 \mathrm{mg} / \mathrm{kg}$ b.w.).
\end{abstract}

Conclusion: The results substantiate traditional usage and recommend the potential utilization of Carica papaya leaves for its' beneficial therapeutic effects.

Keywords: Anti-hyperlipidemic, Carica papaya leaves, Innovative extraction methods, Polyphenols

\section{Background}

Researchers are currently looking around plants and plant based health-promoting compounds to be used in food for prevention of various human diseases. Overall, approximately $80 \%$ population of the developing world depends directly on plant sources for the primary health care (Tripathi and Tripathi 2003). These natural

\footnotetext{
*Correspondence: monaamohsen@yahoo.com

${ }^{1}$ Chemistry of Medicinal Plants Department, National Research Centre, 33

El Bohouth st. (Former El Tahrir St.), Dokki, Giza P.0.12622, Egypt

Full list of author information is available at the end of the article
}

compounds have shown many advantages over synthetic drugs, being available, less cost and with negligible side effects (Wang et al. 2007).

Papaya (Carica papaya) is a tropical tree belongs to family Caricaceae, native to South America but now widely cultivated in tropical regions of the world. It is a nutritionally abundant source of vitamins $\mathrm{A}, \mathrm{B}, \mathrm{C}$ and $E$, also a fair source of minerals as calcium and potassium (Wall 2006). It contains digestive enzymes, cyanogenic glucosides, flavonoids, saponins and glucosinolates (Nugroho et al. 2017). These compounds can enhance the antioxidant potential in the blood and decrease lipid 
peroxidation level, hence, papaya has many therapeutic properties including, anticancer, anti-inflammatory, antibacterial and hypoglycemic effect (Aravind et al. 2013; Rahmani and Aldebasi 2016).

Modern extraction methods have been gaining popularity, among which, ultrasonic extraction, microwave extraction methods that may help in retaining high quality of bioactive compounds in relatively considerable amounts, while optimizing parameters significant in economic terms. These methods besides reducing extraction time, largely enable minimizing the amount of solvent used (AbdelMohsen et al. 2014; Saleh et al. 2016).

Papaya is cultivated in Egypt and successfully growing but still in restricted areas. The objective of the present study is to determine the potential of anti-hyperlipidemic properties of Carica papaya leaves on experimental animals and impact of different extraction methods; microwave-assisted, ultrasonic-assisted and conventional maceration, on extract yield, polyphenols and flavonoids total contents and composition, being comparatively evaluated by HPLC analysis.

\section{Methods}

\section{Plant material}

Fresh leaves of Carica papaya Linn. were collected in November-2018 from the plant cultivated in Al-Aziziyah Gardens Resort, Cairo Alexandria Desert Road, kilo 63, Giza under the supervision of Dr. Kamal Zayed, professor of Ecology, Faculty of science, Cairo University (complying with national guidelines). The collected leaves were dried in an air oven at $30{ }^{\circ} \mathrm{C}$, then grounded using an electric mill into coarse powder and kept in tightlyclosed containers. A voucher specimen was kept at the NRC herbarium (No. 3237).

\section{Extraction}

\section{Conventional maceration extraction}

This extraction (CME) was performed at room temperature by mixing $50 \mathrm{~g}$ of powdered Carica papaya dried leaves with $80 \%$ aqueous ethanol $(200 \mathrm{ml} \times 3)$ in a sealed conical flask.

\section{Ultrasonic-assisted extraction}

Powdered Carica papaya dried leaves (50 g) and $200 \mathrm{ml}$ $80 \%$ aqueous ethanol were mixed in a sealed $250 \mathrm{~mL}$ Erlenmeyer flask $[\approx 8 \mathrm{~cm}$ bottom diameter] and subjected to indirect sonication (Vinatoru 2001) by immersing the flask in an ultrasonic bath [Sonomatic 375TT $40 \mathrm{kHz}$ system, power $=200 \mathrm{~W}$, model: S0375T, Langford Electronics Ltd., Coventry, UK] for UAE. The conical flask was kept below the water level $\approx 4 \mathrm{~cm}$ from the bottom of the flask, exactly over the ultrasonic transducer with the temperature maintained constant $\left[25^{\circ} \mathrm{C} \pm 5{ }^{\circ} \mathrm{C}\right]$ by using ice directly into the bath [keeping the level of water constant in the bath]. The temperature was monitored during extraction using a thermocouple.

\section{Microwave-assisted extraction}

Powdered Carica papaya dried leaves $(50$ g) were extracted by $200 \mathrm{ml} 80 \%$ aqueous ethanol using a monomode focused microwave apparatus (MAE), with a closed-vessel system (CEM Corporation, Matthews, NC, USA; model MARS 240/50, No. 907511, frequency $2450 \mathrm{MHz}$ ) to provide continuous non-pulse heating on a single cavity where the sample was placed. Extraction temperature was set at $60^{\circ} \mathrm{C}$ and extraction time for 20 min with a radiation output at $800 \mathrm{~W}$ power (Saleh et al. 2017). After the extraction time had elapsed, the vessel was allowed to cool at room temperature, and the extract was filtered.

\section{General procedures for post-extraction processing}

After each extraction using all of the above methods, the extracts were filtered through a Fisher brand filter paper (QL100, $150 \mathrm{~mm}$ ) and then the supernatant was evaporated to dryness under reduced pressure at $45{ }^{\circ} \mathrm{C}$ and stored at $18{ }^{\circ} \mathrm{C}$ for subsequent total phenolic, total flavonoid and HPLC analysis.

\section{Determination of total phenolic content}

Determination of total phenolic content (TPC) was according to the Folin-Ciocalteu method (Singleton et al. 1999). An aliquot $(150 \mu \mathrm{l})$ of $100 \mu \mathrm{g} / \mathrm{ml}$ of each extract was separately added to $0.5 \mathrm{ml}$ of distilled water and $125 \mu \mathrm{l}$ of the Folin-Ciocalteu reagent. The mixture was shaken and allowed to stand for $6 \mathrm{~min}$, then $1.25 \mathrm{ml}$ of $\mathrm{Na}_{2} \mathrm{CO}_{3}$ (7\%) was added. The solution was adjusted with distilled water to reach a volume of $3 \mathrm{ml}$, well mixed, and then held in darkness for $90 \mathrm{~min}$ at ambient temperature. After which, the absorbance was measured at $760 \mathrm{~nm}$. The TPC was determined in triplicate. A calibration curve was obtained using gallic acid (Sigma-Aldrich Chemicals Co., St. Louis, MO, USA) as a standard (from 50 to $250 \mathrm{mg} / \mathrm{L}$ ). The results (mean of triplicates) were expressed as gallic acid equivalents $\mathrm{mg} / \mathrm{g}$ of dry plant weight.

\section{Determination of total flavonoid content}

The total flavonoid content (TFC) was determined according to a colorimetric assay (Chang et al. 2002) based on the formation of a flavonoid-aluminium complex which has the absorptivity maximum at $510 \mathrm{~nm}$, and using quercetin (Sigma-Aldrich Chemicals Co., St. Louis, MO, USA) as a standard for a calibration curve. $1 \mathrm{ml}$ of diluted sample (each extract, separately) was mixed with $1 \mathrm{ml}$ of $2 \%$ aluminum chloride methanolic solution. After 
incubation at room temperature for $15 \mathrm{~min}$, absorbance was measured. Results were taken in triplicate (the mean was used) and expressed as quercetin equivalents $\mathrm{mg} / \mathrm{g}$ of dry plant weight.

\section{Quantification of phenolic compounds by HPLC analysis}

Serial dilutions of phenolic acid and flavonoid standards (Sigma-Aldrich Chemicals Co., St. Louis, Mo, USA) were prepared from methanol solution (HPLC grade, Merck, Germany) by double-distilled water and quantified. Then, standard calibration curves were established by injecting various standard concentrations the system. Analyses were developed by HPLC system (Agilent Technologies, Waldbronn, Germany, modular model 1200 series instrument), equipped with Eclipse $\mathrm{DBC}_{18}$ column ( $5 \mu \mathrm{m}, 4.6 \times 250 \mathrm{~mm}$ i.d.) according to Neo et al. (2010). For isocratic elution, acidified water and acetonitrile in the ratio of 90:10 (v/v) was used as a mobile phase at a flow rate of $1 \mathrm{ml} / \mathrm{min}$. A diode array detector (DAD) at 280 and $320 \mathrm{~nm}$ was used. Injection volume was $20 \mu \mathrm{L}$ for all samples. Phenolic compounds identification was based on retention time signals acquired and processed using a Chemstation soft-ware and compared to those of standards. Quantitation in each gram of sample was carried out using external standard method. The concentration of each of the phenolics was calculated using peak area and the calibration curves obtained from the phenolics standard solutions. Concentration of each phenolic compound was expressed as milligrams / gram of dry plant weight $(\mathrm{mg} / \mathrm{g})$. HPLC analysis for the determination of flavonols was carried out using 5\% acetic acid and acetonitrile in a gradient elution mode and column temperature of $30^{\circ} \mathrm{C}$. Phytochemical analysis procedure is shown in Fig. 1.

\section{Evaluation of anti-hyperlipidemic activity Animals}

Forty albino male rats of Sprauge Dawely strain of 130$150 \mathrm{~g}$ b.wt. were obtained from the Animal House of the Horticulture Research Institute. The rats were acclimatized to conventional laboratory conditions, at room temperature $\left(20-25^{\circ} \mathrm{C}\right)$ having free access to food and water. The procedure in this study was subjected to the scrutiny of the NRC (FWA 00014747) Animal Ethics Committee and was approved before beginning of the experiment (certificate no. 19087).

\section{Determination of $\mathrm{LD}_{50}$ of the extract}

For acute oral toxicity study and $\mathrm{LD}_{50}$ determination, Karber procedure (Karber 1931) was applied and the Organization for Economic Co-operation and Development (OECD 2000 guideline 425) was followed.

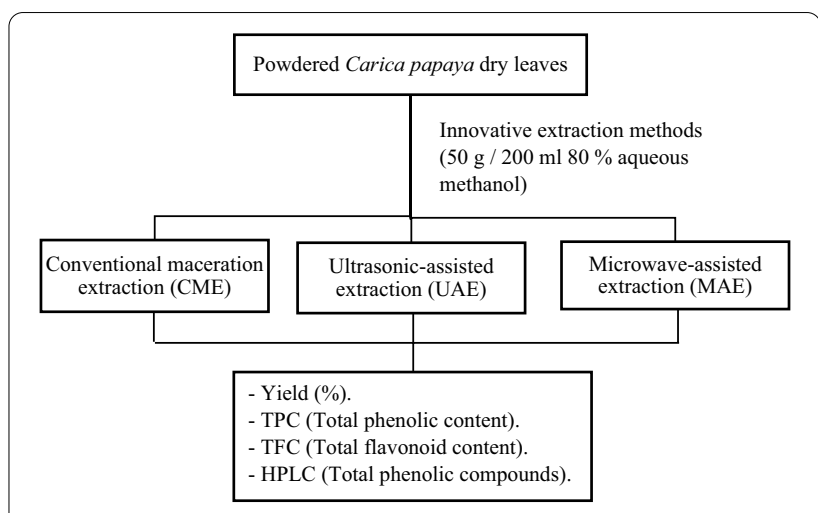

Fig. 1 Schematic presentation of phytochemical analysis of Carica papaya dry leaves extracts

\section{Experimental design}

The selected animals were grouped randomly into five groups $(n=8)$. To first group (negative control group) only tap water was administered with standard diet, whereas the other groups received hyperlipidemic diet (high cholesterol 1\%), by adding cholesterol powder, $0.2 \%$ cholic acid, $10 \%$ fat to the rat's chow daily for 8 weeks before starting treatment and continued for experiment duration, animals were weighed. Upon starting the experiment, the second group (positive hyperlipidemic group) received daily oral dose of $1 \mathrm{ml}$ drinking water. The third and fourth groups (hyperlipidemic) received daily dose of 100 and $200 \mathrm{mg} /$ $\mathrm{kg}$, respectively of $80 \%$ total ethanol extract of Carica papaya leaves obtained by microwave assisted extraction (MAE) showing the highest phenolic content. The fifth group (hyperlipidemic) is considered the reference group, whereas the rats received simvastatin drug $(0.18 \mathrm{mg} / \mathrm{kg}$ b. w. $)$ dissolved in drinking water daily. After overnight fasting, animals were weighed again and anesthetized with diethyl ether (by exposing to ether on a cotton ball 1.9\% /L of container volume, in a small closed chamber for 2-5 min) (Goodies et al. 2015). Dead animals were incinerated in the National Research Centre incinerator. Blood samples were drawn from retro-orbital plexus before starting treatment (zero), and then after 4 and 8 weeks of treatment. Serum was separated by centrifugation. Biochemical parameters including serum total cholesterol (Allain et al. 1974), serum triglyceride (Bucolo and David 1973), serum LDL cholesterol (Muniz and Bastida 2008) and serum HDL cholesterol (Burstein et al. 1970) were estimated. Then, atherogenic index (AI, LDLcholesterol/HDL-cholesterol) was calculated (Beyegue et al. 2012). A schematic presentation of the in vivo experiment is given in Fig. 2 (see Additional file 1). 


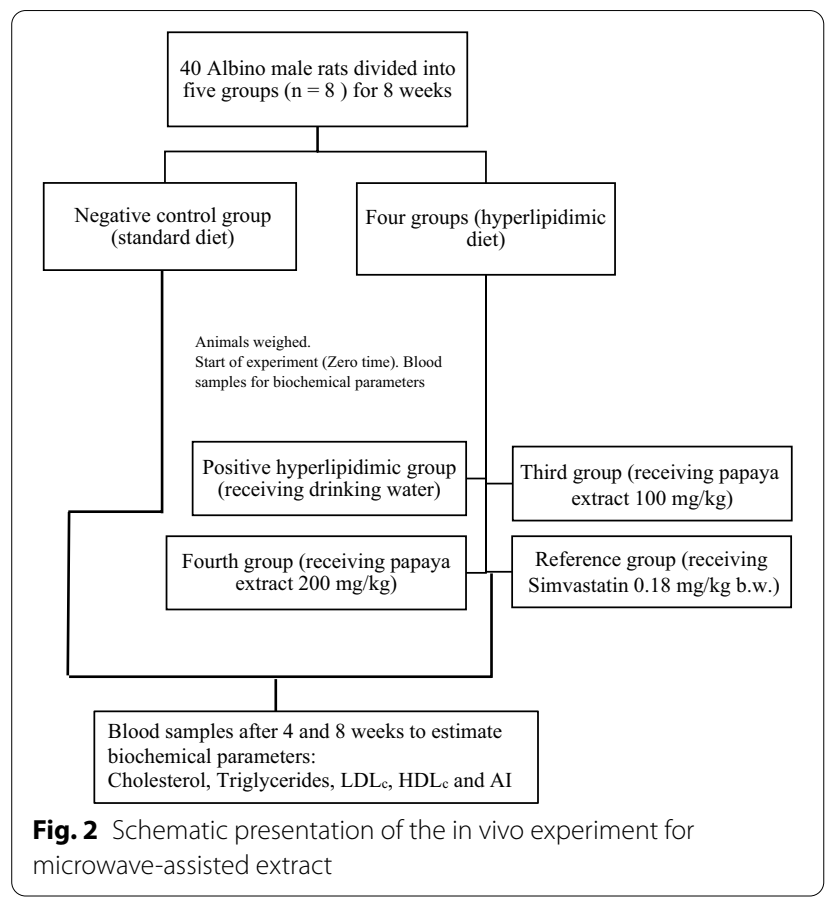

\section{Statistical analysis}

All data are expressed as mean \pm S.E. One-way analysis of variance (ANOVA) was performed among groups, followed by Duncan's Post Hoc test to assess the significant difference between treatments. ' $P$ ' value less than 0.05 was considered as statistically significant.

\section{Results}

\section{Extraction yield, total phenolic and total flavonoid content} of extracts

Microwave-assisted extraction (MAE) produced the highest extract yield, total phenolic and flavonoid contents $(16.90 \%, 44.46 \mathrm{mg} \mathrm{GAE} / \mathrm{g}$ DW and $14.40 \mathrm{mg} \mathrm{QE} / \mathrm{g}$ DW, respectively), ultrasonic-assisted extraction (UAE) gave $(16.80 \%$, $43.46 \mathrm{mg} \mathrm{GAE} / \mathrm{g} \mathrm{DW}$ and $13.40 \mathrm{mg}$ QE/g DW, respectively) and conventional maceration extraction (CME) showed the lowest parameters (15.66\%, $43.33 \mathrm{mg} \mathrm{GAE} / \mathrm{g}$ DW and $13.28 \mathrm{mg} \mathrm{QE} / \mathrm{g}$ respectively) as presented in Table 1, showing the impact of the extraction method on the phenolic compounds content in the extracts obtained.

\section{HPLC analysis}

The content of polyphenolic compounds and phenolic acids depended on the applied extraction method (Table 2). The highest content of phenolic compounds was characterized by MAE $(29.99 \mathrm{mg} / \mathrm{g})$, the HPLC chromatogram is given in Fig. 3, followed by UAE
Table 1 Extraction yield, total phenolic and flavonoid contents of applied extraction methods of Carica papaya leaves

\begin{tabular}{|c|c|c|c|}
\hline \multirow[t]{2}{*}{ Parameter } & \multicolumn{3}{|c|}{$\begin{array}{l}\text { Extraction method } \\
50 \mathrm{~g} \text { Carica papaya }\end{array}$} \\
\hline & $\begin{array}{l}\text { Conventional } \\
\text { maceration } \\
\text { (CME) }\end{array}$ & $\begin{array}{l}\text { Ultrasonic- } \\
\text { Assisted } \\
\text { extraction } \\
\text { (UAE) }\end{array}$ & $\begin{array}{l}\text { Microwave- } \\
\text { assisted } \\
\text { extraction } \\
\text { (MAE) }\end{array}$ \\
\hline Yield \% & $15.66 \%$ & $16.80 \%$ & $16.90 \%$ \\
\hline $\begin{array}{l}\text { Total phenolic } \\
\text { content } \\
\text { (mg GAE/g DW) }\end{array}$ & $43.33 \pm 3.50$ & $43.46 \pm 3.61$ & $44.46 \pm 4.11$ \\
\hline $\begin{array}{l}\text { Total flavonoid } \\
\text { content } \\
\text { (mg QE/g DW) }\end{array}$ & $13.28 \pm 2.10$ & $13.40 \pm 1.90$ & $14.40 \pm 3.22$ \\
\hline
\end{tabular}

GAE gallic acid equivalent, $Q E$ quercetin equivalent

Results are mean values of three readings \pm standard deviation

$(24.75 \mathrm{mg} / \mathrm{g})$, and the lowest content of these compounds was found in CME $(22.64 \mathrm{mg} / \mathrm{g})$. The most abundant phenolic acid extracted was gallic acid (3.37$4.06 \mathrm{mg} / \mathrm{g}$ ) followed by caffeic acid (3.03-3.88), notice that, ferulic acid was identified only in UAE and MAE ( 0.75 and $0.89 \mathrm{mg} / \mathrm{g}$ respectively). The most abundant flavonoid was rutin $(3.65-4.4 \mathrm{mg} / \mathrm{g})$. In addition, high

Table 2 HPLC analysis of phenolic compounds in Carica papaya leaves (80\% ethanol extracts)

\begin{tabular}{llll}
\hline Compound $(\mathbf{m g} / \mathbf{g})$ & \multicolumn{1}{l}{ CME } & \multicolumn{1}{l}{ UAE } & \multicolumn{1}{l}{ MAE } \\
\hline Gallic acid & $3.37 \pm 1.67$ & $3.27 \pm 1.55$ & $4.06 \pm 1.24$ \\
Chlorogenic acid & $2.11 \pm 0.12$ & $2.20 \pm 0.15$ & $2.21 \pm 0.16$ \\
Catechin & $1.10 \pm 0.05$ & $2.16 \pm 0.13$ & $2.51 \pm 0.26$ \\
Methylgallate & $0.42 \pm 0.04$ & $0.39 \pm 0.02$ & $0.47 \pm 0.05$ \\
Caffeic acid & $3.03 \pm 1.06$ & $3.53 \pm 1.66$ & $3.88 \pm 1.76$ \\
Syringic acid & $3.00 \pm 2.98$ & $3.07 \pm 1.88$ & $3.33 \pm 2.35$ \\
Pyro catechol & $0.97 \pm 0.14$ & $1.02 \pm 0.01$ & $1.10 \pm 0.06$ \\
Rutin & $3.65 \pm 1.97$ & $3.70 \pm 2.05$ & $4.40 \pm 2.38$ \\
Ellagic acid & $0.58 \pm 0.08$ & $0.69 \pm 0.10$ & $0.74 \pm 0.20$ \\
p-Coumaric acid & $0.05 \pm 0.65$ & $0.09 \pm 0.87$ & $0.11 \pm 1.01$ \\
Vanillic acid & $1.30 \pm 0.06$ & $1.45 \pm 0.08$ & $1.58 \pm 1.01$ \\
Ferulic acid & 0.00 & $0.75 \pm 0.30$ & $0.89 \pm 0.50$ \\
Naringenin & $2.23 \pm 0.32$ & $1.09 \pm 0.03$ & $2.33 \pm 0.35$ \\
Taxifolin & $0.19 \pm 0.05$ & $0.41 \pm 0.50$ & $0.42 \pm 0.05$ \\
Cinnamic acid & $0.04 \pm 0.55$ & $0.06 \pm 0.56$ & $0.05 \pm 0.55$ \\
Kaempferol & $0.11 \pm 0.34$ & $0.19 \pm 0.54$ & $0.50 \pm 0.80$ \\
Quercetin & $0.15 \pm 0.36$ & $0.18 \pm 0.55$ & $0.43 \pm 0.76$ \\
Apigenin & $0.14 \pm 0.22$ & $0.18 \pm 0.55$ & $0.54 \pm 0.77$ \\
Luteolin & $0.20 \pm 0.54$ & $0.32 \pm 0.34$ & $0.44 \pm 0.67$ \\
Total phenolic compounds & $22.64 \pm 2.34$ & $24.75 \pm 3.67$ & $29.99 \pm 4.09$ \\
\hline Resltaremen vas & & &
\end{tabular}

Results are mean values of three readings \pm standard deviation 


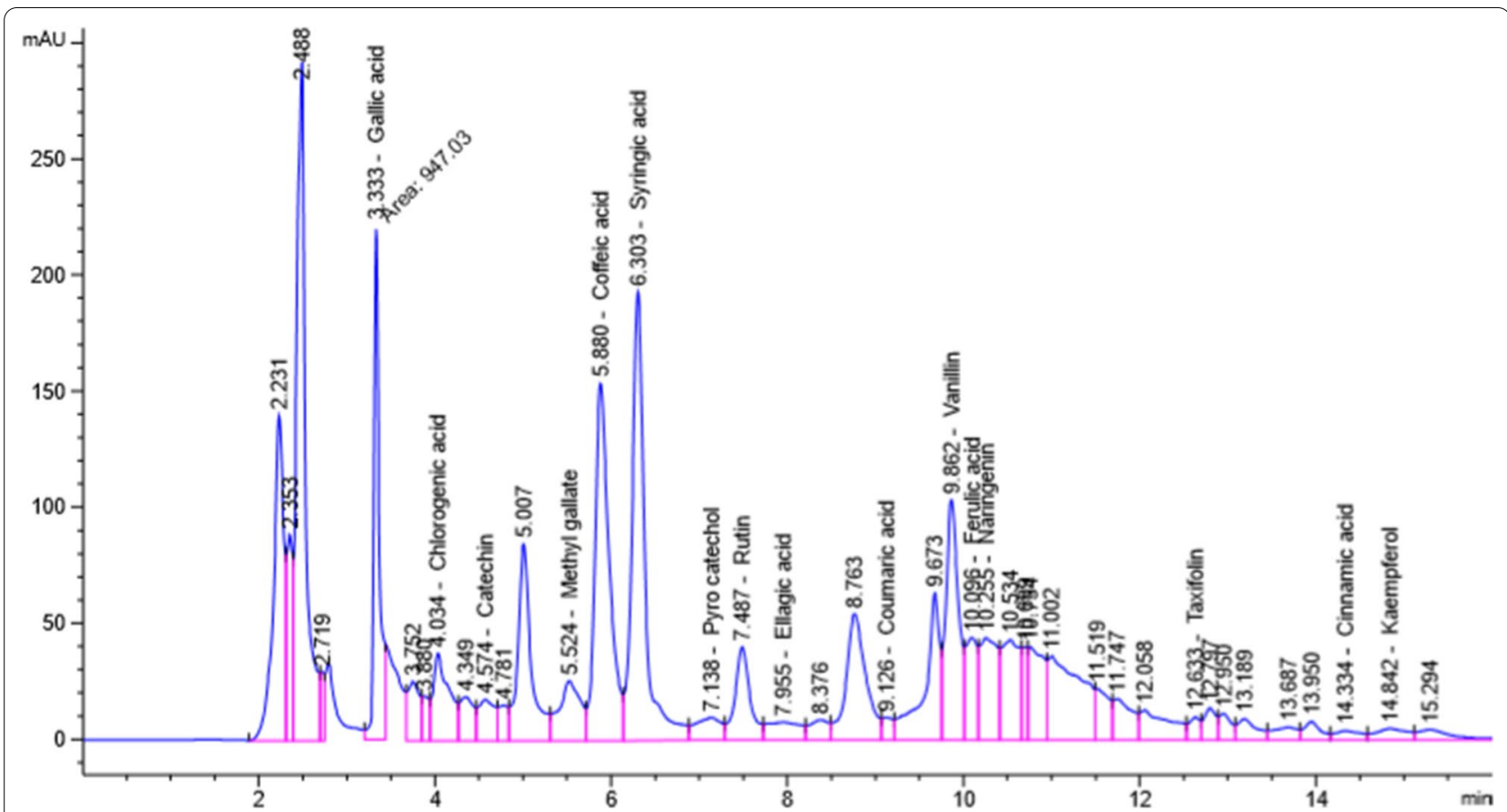

Fig. 3 HPLC chromatogram of phenolic compounds in 80\% ethanol extract of Carica papaya L. leaves extracted by microwave extraction method

contents of catechin, naringenin, chlorogenic and syringic acids have been identified in the extracts.

\section{Determination of $\mathrm{LD}_{50}$ of the extract}

Administration of dose $(500 \mathrm{mg} / \mathrm{kg}$, b.w.) of MAE leaves extract did not produce any mortality. All animals were alive, healthy, and active during the observation period of experiment (14 days). AOT 425 software was used to apply higher doses for $\mathrm{LD}_{50}$ determinations as per the OECD guidelines. The computer program suggested doses up to $2000 \mathrm{mg} / \mathrm{kg}$. Results indicate that the doses up to $2000 \mathrm{mg} / \mathrm{kg}$ were nonlethal. All the animals were found to be alive and healthy after the administration of highest dose. The computer program showed $\mathrm{LD}_{50}>2000 \mathrm{mg} / \mathrm{kg}$.

\section{Anti-hyperlipidemic activity}

The results of feeding hyperlipidemic diet on experimental rats after 8 weeks are shown in Table 3. It showed a significant increase in weight of rats fed on hyperlipidemic diet compared to rats fed on standard diet after 4 weeks and 8 weeks.

Drastic increase in the lipid profile was observed in the rats fed on hyperlipidemic diet. There was a significant increase in cholesterol, triglycerides and $\mathrm{LDL}_{\mathrm{c}}$ in hyperlipidemic rats $(P<0.01)$, and the level of $\mathrm{HDL}_{\mathrm{c}}$ was significantly decreased $(P<0.01)$ when compared to standard fed rats (Table 4), consequently, elevated atherogenic
Table 3 Effect of feeding hyperlipidemic diet on experimental rats after 4 and 8 weeks

\begin{tabular}{lll}
\hline Time & Weight & \\
\cline { 2 - 3 } & $\begin{array}{l}\text { Standard diet } \\
\text { (negative gp) }\end{array}$ & $\begin{array}{l}\text { Hyperlipidemic diet } \\
\text { (average of four gps) }\end{array}$ \\
\hline Zero time & $132.60 \pm 3.70$ & $133.90 \pm 3.50$ \\
4 weeks & $145.20 \pm 3.40$ & $167.20 \pm 4.60^{\mathrm{a}}$ \\
8 weeks & $164.40 \pm 4.20$ & $194.80 \pm 5.90^{\mathrm{a}}$ \\
\hline
\end{tabular}

${ }^{a}$ Significantly different from negative gp at $P<0.01$

All values: Mean \pm S.E

index (AI) was observed. The effect of ethanolic extract (MAE) of Carica papaya on serum lipid profiles in the experimental rats are shown in Table 4. Administration of 100 and $200 \mathrm{mg} / \mathrm{kg}$ per day of the ethanol extract of Carica papaya showed significant decrease in cholesterol $(P<0.05)$, triglycerides and $\mathrm{LDL}_{\mathrm{C}}(P<0.01)$, as compared to hyperlipidemic untreated rats (positive gp). At the same time, an increase in the level of $\mathrm{HDL}_{\mathrm{C}}$ was significantly observed $(P<0.01)$. Both 100 and $200 \mathrm{mg} /$ $\mathrm{kg}$ per day of the ethanol extract of Carica papaya treatment showed decrease in atherogenic index, and thus increased percentage of protection. Notice that, treatment with $200 \mathrm{mg} / \mathrm{kg}$ of the extract retained the lipid profile to be compatible to the results of those (reference gp) receiving simvastatin $(0.18 \mathrm{mg} / \mathrm{kg}$ b.w. $)$. 
Table 4 Effect of ethanolic extract (MAE) of Carica papaya on lipid profile in hyperlipidemic rats

\begin{tabular}{|c|c|c|c|c|c|}
\hline \multicolumn{3}{|l|}{ Parameter } & \multicolumn{3}{|l|}{ Groups } \\
\hline Experiment duration & $\begin{array}{l}\text { Negative } \\
\text { gp }\end{array}$ & $\begin{array}{l}\text { Positive } \\
\text { gp }\end{array}$ & $\begin{array}{l}\text { Papaya extract } \\
(100 \mathrm{mg} / \mathrm{kg}) \mathrm{gp}\end{array}$ & $\begin{array}{l}\text { Papaya extract } \\
(200 \mathrm{mg} / \mathrm{kg}) \mathrm{gp}\end{array}$ & $\begin{array}{l}\text { Simvastatin } \\
\text { (reference gp) }\end{array}$ \\
\hline \multicolumn{6}{|l|}{ Cholesterol } \\
\hline Zero & $91.8 \pm 2.1$ & $162.3 \pm 5.4$ & $168.7 \pm 5.1$ & $171.2 \pm 4.3$ & $195.4 \pm 3.6$ \\
\hline 4 weeks & $92.7 \pm 2.3$ & $184.2 \pm 5.6^{\mathrm{a}}$ & $136.8 \pm 4.3^{\mathrm{a}}$ & $112.3 \pm 3.8^{\mathrm{a}}$ & $128.1 \pm 3.4^{\mathrm{a}}$ \\
\hline 8 weeks & $89.6 \pm 1.9$ & $189.4 \pm 5.5^{\mathrm{a}}$ & $111.2 \pm 3.7^{\mathrm{a}}$ & $98.6 \pm 2.4^{\mathrm{a}}$ & $94.7 \pm 2.2^{\mathrm{a}}$ \\
\hline \multicolumn{6}{|l|}{ Triglycerides } \\
\hline Zero & $57.8 \pm 1.5$ & $83.8 \pm 2.1$ & $89.2 \pm 2.5$ & $88.6 \pm 1.8$ & $86.3 \pm 1.7$ \\
\hline 4 weeks & $59.2 \pm 1.3$ & $92.2 \pm 3.4^{\mathrm{a}}$ & $76.7 \pm 2.8^{\mathrm{a}}$ & $69.1 \pm 2.1^{\mathrm{a}}$ & $73.4 \pm 1.2^{\mathrm{a}}$ \\
\hline 8 weeks & $58.7 \pm 1.4$ & $98.3 \pm 5.7^{\mathrm{a}}$ & $68.3 \pm 2.2^{\mathrm{a}}$ & $61.4 \pm 1.9^{\mathrm{a}}$ & $58.1 \pm 1.3^{\mathrm{a}}$ \\
\hline \multicolumn{6}{|l|}{$L D L_{C}$} \\
\hline Zero & $37.9 \pm 0.6$ & $117.4 \pm 4.6^{\mathrm{a}}$ & $127.0 \pm 4.3$ & $130.6 \pm 4.9^{\mathrm{a}}$ & $154.5 \pm 6.2$ \\
\hline 4 weeks & $37.3 \pm 0.4$ & $141.2 \pm 4.8^{\mathrm{a}}$ & $93.6 \pm 3.2^{\mathrm{a}}$ & $51.2 \pm 1.8^{\mathrm{a}}$ & $80.5 \pm 2.4^{a}$ \\
\hline 8 weeks & $35.8 \pm 0.5$ & $147.0 \pm 3.9^{\mathrm{a}}$ & $68.2 \pm 2.4^{\mathrm{a}}$ & $46.5 \pm 1.9^{\mathrm{a}}$ & $41.7 \pm 1.9^{\mathrm{a}}$ \\
\hline \multicolumn{6}{|l|}{$H D L_{C}$} \\
\hline Zero & $42.3 \pm 0.9$ & $28.3 \pm 0.6$ & $23.9 \pm 0.3$ & $22.9 \pm 0.8$ & $23.6 \pm 0.7$ \\
\hline 4 weeks & $43.6 \pm 0.1$ & $24.6 \pm 0.3^{a}$ & $28.2 \pm 0.6$ & $33.6 \pm 1.2^{\mathrm{a}}$ & $32.9 \pm 0.8^{\mathrm{a}}$ \\
\hline 8 weeks & $42.1 \pm 0.8$ & $22.7 \pm 0.4^{\mathrm{a}}$ & $32.7 \pm 0.4$ & $39.8 \pm 1.3^{\mathrm{a}}$ & $41.6 \pm 1.2^{\mathrm{a}}$ \\
\hline \multicolumn{6}{|l|}{ Al } \\
\hline Zero & 0.90 & 1.60 & 5.30 & 5.70 & 6.60 \\
\hline 4 weeks & 0.86 & 5.70 & 3.30 & 1.50 & 2.50 \\
\hline 8 weeks & 0.85 & 6.50 & 2.10 & 1.20 & 0.96 \\
\hline
\end{tabular}

${ }^{a}$ Significantly different from zero time at $P<0.01$

All values: Mean \pm S.E

$\mathrm{Al}=\mathrm{LDL}_{\mathrm{C}} / \mathrm{HDL_{ \textrm {C } }}$

\section{Discussion}

Recent studies have recommended that consuming high levels of plant derived foods leads to low incidence rates of multiple diseases. These findings implicate the protective role of plant phenolics in increasing the average life span and promoting human health. Plants consumed by humans contain thousands of dietary polyphenols, the intake of which are of great importance to control the balance between free radicals and antioxidant potential. Considerably, it is necessary to optimize these raw materials in order to acknowledge and provide consumers with functional products having the designed, efficient action (Bungau et al. 2019).

The conducted study clarified that the method of extraction of plant material has considerable impact on the extract yield and content of phenolic and bioactive compounds which guarantee the biological potential. Great attention has been devoted to innovative extraction methods with significant improvements offering lowered extraction time, environmental risk and enhanced efficiency. These methods include microwaveassisted extraction (MAE) and ultrasonic-assisted extraction (UAE) as alternatives to conventional methods
(Mason et al. 2011). MAE is an extraction technology that can be used both on a small and large scale in industry for extraction of medicinal plants. It allows bioactive compounds to be extracted more rapidly, lower costs and greener features with similar or better yields as compared to conventional extraction methods (Afoakwah et al. 2012; Dahmoune et al. 2015). Its efficiency depends on the tremendous amount of intracellular pressure produced due to microwave radiation, which allows the energy to be strongly absorbed by the plant matrices, causing complete rupture to the cell wall, facilitating the active constituents to be rapidly released from the ruptured cells into the surrounding solvent (Saleh et al., 2017). UAE is a useful technique that is used equally well on either a small or large scale in the phytopharmaceutical applications thus, moving towards industrial acceptance (Wang and Weller 2006). UAE has many advantages, other than increasing the extraction efficiency, including shorter extraction time and less solvent consumption. These advantages are contributed to the mechanical effect of ultrasonic waves allowing greater penetration of solvent into plant matrix. When the solvent is ultrasonically irradiated acoustic cavitation bubbles occur. 
Bubbles form, grow and suddenly collapse producing tremendous amounts of localized energy. In a system containing solid particles the bubbles collapse releasing high temperatures and pressures $\left[\sim 5000^{\circ} \mathrm{K}\right.$ and $\left.\sim 2000 \mathrm{~atm}\right]$ but also create a high-speed jet which is directed towards the plant particles, allowing better penetration of solvent. The jets could also lead to cells pores enlargement acting like a micro-pump forcing the solvent into the cell, thus helping to dissolve the compounds and transport them into the bulk solvent (Briars and Paniwnyk 2013). Our study lined up that these innovative techniques are effective. MAE produced the highest extract yield, total phenolic and flavonoid contents (16.90\%, $44.46 \mathrm{mg}$ GAE/g DW and $14.40 \mathrm{mg}$ QE/g DW, respectively), UAE gave (16.80\%, $43.46 \mathrm{mg}$ GAE/g DW and $13.40 \mathrm{mg} \mathrm{QE/g} \mathrm{DW,}$ respectively) and CME showed the lowest parameters (15.66\%, $43.33 \mathrm{mg}$ GAE/g DW and $13.28 \mathrm{mg} \mathrm{QE/g} \mathrm{DW,}$ respectively).

The leaves of papaya have been shown to contain many active components that can promote the total antioxidant power such as saponins, cardiac glycosides, flavonoids, phenolic acids, ascorbic acid, tocopherol and alkaloids (Ikeyi et al. 2013; Vyas et al. 2014). In a previous study, we analyzed the essential minerals, lipid constituents, isolated carpaine alkaloid and investigated the in-vivo potential of the leaves aqueous ethanol extract of Carica papaya as antioxidant and hepatoprotective, and it demonstrated compatible results to references (Abdel-Halim et al. 2020). Hereby, we investigated the anti-hyperlipidemic activity of the leaves aqueous ethanol extract of Carica papaya obtained by MAE, which relatively contained the highest phenolic and flavonoids contents, the presence of which could account for the observed biological effects (Olagunju et al. 1995). Both 100 and $200 \mathrm{mg} /$ $\mathrm{kg}$ per day of the extract treatment showed significant hypolipidemic results, decrease in atherogenic index (the higher of which indicates the higher is the risk of body organs for oxidative damage) (Mehta et al. 2003) and thus increased percentage of protection. Notice that, treatment with $200 \mathrm{mg} / \mathrm{kg}$ of the extract retained the lipid profile to be compatible to the results of those (reference gp) receiving simvastatin $(0.18 \mathrm{mg} / \mathrm{kg}$ b.w.). Accordingly, the extract induced significant, steady and progressive hypolipidemia as the dose of the extract increased, notice that, the relative oral safety dose of the extract is higher than $2000 \mathrm{mg} / \mathrm{kg}$, thus the extract could be considered of low toxicity and relatively safe on acute oral exposure. Previous studies have reported that some phytocomponents, particularly saponins and steroids, elicit antihyperlipidemic action by inhibiting intestinal lipid absorption via resin-like action and inhibition of lipase activity (Adeneye et al. 2010). Beta sitosterol, a phytosterol detected in papaya (Abdel-Halim et al. 2020) was reported as useful in the treatment of hyperlipidemia (Bopanna et al., 1997). Thus, the suggested mechanism for Carica papaya could be attributed to sterols which decrease the activity of lipid- and carbohydrate-hydrolyzing enzymes in the small intestine, therefore reducing the conversion of disaccharides and triglycerides into absorbable monosaccharides and free fatty acids (Banerjee et al. 2006). Also, papaya juice was reported to reduce total cholesterol and triglycerides in high-fat diet fed rats by interfering with their biosynthesis (Banerjee et al. 2006). Nevertheless, the simultaneous administration of these extracts lowered lipid levels on one hand and quenched miscellaneous peroxidation mechanisms on the other hand thereby, alleviating the free radical and lipid peroxidative pathways very significantly.

\section{Conclusion}

In terms of green and environmental chemistry, the influence of innovative extraction techniques was studied on the Carica papaya leaves in an approach to obtain highly phenolic extracts. The present study investigated the influence of Carica papaya leaves extract as hypolipidemic using the in vivo animal model. The results revealed that both 100 and $200 \mathrm{mg} / \mathrm{kg}$ per day of the microwave assisted extract restored hyperlipidemic effects, decreased atherogenic index and retained the lipid profile to reference levels.

In recent years, the use of therapeutic phytoproducts has been consistent. Carica papaya is a neutraceutical plant rich in bioactive phytochemicals which are evident for its significant anti-hyperlipidemic potential and may contribute to the prevention and cure of diseases. Our results encourage wide cultivation, local consumption and application of modern extraction methods. Further investigation to determine the potential use of papaya leaves in the functional food industry could be considered.

\begin{abstract}
Abbreviations
MAE: Microwave-assisted extraction; UAE: Ultrasonic-assisted extraction; CME: Conventional maceration extraction; HPLC: High performance liquid chromatography; LD: Lethal dose; GAE: Gallic acid equivalent; QE: Quercetin equivalent; DW: Dry weight; b.w: Body weight; LDL $_{c}$ : Low-density lipoprotein cholesterol; $\mathrm{HDL}_{c}$ : High-density lipoprotein cholesterol; Al: Atherogenic index.
\end{abstract}

\section{Supplementary Information}

The online version contains supplementary material available at https://doi. org/10.1186/s42269-021-00548-4.

Additional file 1. Ethics approve.

\section{Acknowledgements}

The authors gratefully acknowledge the help of Dr. Kamal Zayed, professor of Ecology, Faculty of science, Cairo University, for sample authentication. 


\section{Authors' contributions}

SA: Carried out the experimental work of the manuscript; AS: Designed the pharmacological work, participated in analysis and interpretation of pharmacological data; MA: Supervised the experimental work, participated in analysis and interpretation of the data, and was the major contributor in writing the manuscript; MI and ME: Designed, supervised the experimental work and reviewed the manuscript. All the authors read and approved the final manuscript.

\section{Funding}

The study was funded by National Research Centre, Cairo, Egypt in providing materials, tools and equipment used for the study.

\section{Availability of data and materials}

The datasets used and analyzed during the current study are available from the corresponding author on reasonable request.

\section{Declarations}

\section{Ethics approval and consent to participate}

The procedure in this study was subjected to the scrutiny of the National Research Centre (FWA 00014747) Animal Ethics Committee and was approved before beginning of the experiment (certificate no. 19087).

\section{Consent for publication}

Not applicable.

\section{Competing interests}

The authors declare that they have no competing interests.

\section{Author details}

${ }^{1}$ Chemistry of Medicinal Plants Department, National Research Centre, $33 \mathrm{El}$ Bohouth st. (Former El Tahrir St.), Dokki, Giza P.0.12622, Egypt. ${ }^{2}$ Pharmacognosy Department, Faculty of Pharmacy, Al-Azhar University (Girls), Cairo, Egypt. ${ }^{3}$ Pharmacology Department, National Research Centre, 33 El Bohouth st. (Former El Tahrir St.), Dokki, Giza P.O.12622, Egypt.

Received: 3 January 2021 Accepted: 27 April 2021 Published online: 08 May 2021

\section{References}

Abdel-Halim SA, Ibrahim MT, Abdel Mohsen MM, Abou-Setta LM, Sleem AA, Morsy FA, El-Missiry MM (2020) Phytochemical and biological investigation of Carica papaya Linn. Leaves cultivated in Egypt (Family (aricaceae). J Pharmacogn Phytochem 9:47-54

AbdelMohsen MM, Nazif NM, Seif EL Nasr MM (2014) Microwave-assisted extraction of bio-active compounds (phenolics and alkamides) from Echinacea purpurea. Int J Pharm Pharm Sci 6(9):265-268

Adeneye AA, Adeyemi OO, Agbaje EO (2010) Anti-obesity and antihyperlipidemic effect of Hunteria umbellate seed extract in experimental hyperlipidemia. J Ethnopharmacol 130:307-314

Afoakwah AN, Owusu J, Adomako C, Teye E (2012) Microwave assisted extraction (MAE) of antioxidant constituents in plant materials. GJBB $1: 132-140$

Allain CC, Poon LS, Chan CS, Richmond W, Fu PC (1974) Enzymatic determination of total serum cholesterol. Clin Chem 20:470-475

Aravind G, Bhowmik D, Duraivel S, Harish G (2013) Traditional and medicinal uses of Carica papaya. J Med Plants Stud 1(1):7-15

Banerjee A, Vaghasiya R, Shrivastava N, Padh H, Nivsarkar M (2006) Antihyperlipidemic effect of Carica papaya L. in Sprague Dawley rats. Niger J Nat Prod Med 10:69-72

Beyegue CFN, Ngangoum RMC, Kuate D, Ngondi JL, Oben JE (2012) Effect of Guibourtiates smannii extracts on blood and oxidative stress markers in triton WR 1339 and high fat diet induced hyperlipidemic rats. Biol Med 4:1-9

Bopanna KN, Bhagyalakshmi N, Rathod SP, Balaraman R, Kannan J (1997) Cell culture derived Hemides musindicus in the prevention of hypercholesterolemia in normal and hyperlipidemic rats. Indian J Pharmacol 29:105-109

Briars R, Paniwnyk L (2013) Effect of ultrasound on the extraction of artemisinin from Artemisia annua. Ind Crops Prod 42:595-600

Bucolo G, David H (1973) Quantitative determination of serum triglycerides by the use of enzymes. Clin Chem 19:476-482

Bungau S, Abdel-Daim MM, Tit DM, Ghanem E, Sato S, Maruyama-Inoue M, Yamane S, Kadonosono K (2019) Health benefits of polyphenols and carotenoids in age-related eye diseases. Oxid Med Cell Longev 2019:9783429

Burstein M, Scholnick HR, Morfin R (1970) Rapid method for the isolation of lipoproteins from human serum by precipitation with polyanions. J Lipid Res 11:583-595

Chang C-C, Yang M-H, Wen H-M, Chern J-C (2002) Estimation of total flavonoid content in Propolis by two complementary colorimetric methods. J Food Drug Anal 10:178-182

Dahmoune F, Nayak B, Moussi K, Remini H, Madani K (2015) Optimization of microwave-assisted extraction of polyphenols from Myrtus communis L. leaves. Food Chem 166:585-595

Goodies ME, Oghenesurwe EE, Ejiroghene A (2015) Effects of inhaled anaesthetic agents (Chloroform and Diethyl ether) on fasting blood glucose and haematological parameters in Wistar rats. Sky J Biochem Res 4(2):013-015

Ikeyi AP, Ogbonna AO, Eze FU (2013) Phytochemical analysis of Paw-paw (Carica papaya) leaves. Int J Life Sci Biotechnol Pharma Res 2:347-351

Karber G (1931) Beitrag zur kollecktiven Behandlung pharmakologischer Reihenversuche. Archiv for Experimentelle Pathologie Und Pharmakologie 162:480-483

Mason TJ, Chemat F, Vinatoru M (2011) The extraction of natural products using ultrasound or microwaves. Curr Org Chem 15:237-247

Mehta LK, Balaraman R, Amin AH, Bafna PA, Gulati OD (2003) Effect of fruits of Moringa oleifera on the lipid profile of normal and hypercholesterolaemic rabbits. J Ethnopharmacol 86:191-195

Muniz FJ, Bastida S (2008) Do not use the Friedewald formula to calculate LDL-cholesterol in hypercholesterolaemic rats. Eur J Lipid Sci Technol 110:295-301

Neo YP, Ariffin A, Tan CP, Tan YA (2010) Phenolic acid analysis and antioxidant activity assessment of oil palm (E. guineensis) fruit extracts. Food Chem 122:353-359

Nugroho A, Heryani H, Choi JS, Park HJ (2017) Identification and quantification of flavonoids in Carica papaya leaf and peroxynitrite scavenging activity. Asian Pac J Trop Biomed 7(3):208-213

OECD (2000) Guidelines 425. Acute oral toxicity. Environmental Health and Safety Monograph Series on Testing and Assessment, p 24

Olagunju JA, Ogunlana CO, Gbile ZO (1995) The hypoglycemic activity of ethanolic extracts of unripe, mature fruits of Carica papaya in alloxaninduced diabetic rats. Niger J Biochem Mol Biol 10:21-23

Rahmani AH, Aldebasi YH (2016) Potential role of Carica papaya and their active constituents in the prevention and treatment of diseases. Int J Pharm Pharm Sci 8(1):11-15

Saleh IA, Vinatoru M, Mason TJ, Abdel-Azim NS, Aboutabl EA, Hammouda FM (2016) A possible general mechanism for ultrasound-assisted extraction (UAE) suggested from the results of UAE of chlorogenic acid from Cynara scolymus L. (artichoke) leaves. Ultrason Sonochem 31:330-336

Saleh IA, Vinatoru M, Mason TJ, Abdel-Azim NS, Shams KA, Aboutabl EA, Hammouda FM (2017) Extraction of silymarin from milk thistle (Silybum marianum) seeds - a comparison of conventional and microwaveassisted extraction methods. J Microw Power Electromagn Energy 51(2):124-133

Singleton VL, Orthofer R, Lamuela-Raventos RM (1999) Analysis of total phenols and other oxidation substrates and antioxidants by means of Folin-Ciocalteu reagent. Methods Enzymol 299:152-178

Tripathi L, Tripathi JN (2003) Role of biotechnology in medicinal plants. Trop J Pharm Res 2(2):243-253

Vyas SJ, Taslim TK, Vijay RR, Pragneshand ND, Hitendra SJ (2014) Biochemical constituents in leaf of Carica papaya-ethnomedicinal plant of Kachchh region. Int Lett Nat Sci 7:16-20

Vinatoru M (2001) An overview of the ultrasonically assisted extraction of bioactive principles from herbs. Ultrason Sonochem 8:303-313 
Wall MM (2006) Ascorbic acid, vitamin A, and mineral composition of banana (Musa sp.) and papaya (Carica papaya) cultivars grown in Hawaii. J Food Compos Anal 19:434

Wang L, Weller CL (2006) Recent advances in extraction of nutraceuticals from plants. Trends Food Sci Technol 17:300-312

Wang MW, Hao X, Chen K (2007) Biological screening of natural products and drug innovation in China. Philos Trans R Soc Lond B Biol Sci 362(1482):1093-1105

\section{Publisher's Note}

Springer Nature remains neutral with regard to jurisdictional claims in published maps and institutional affiliations.

\section{Submit your manuscript to a SpringerOpen ${ }^{\circ}$ journal and benefit from:}

- Convenient online submission

- Rigorous peer review

- Open access: articles freely available online

- High visibility within the field

- Retaining the copyright to your article

Submit your next manuscript at $\boldsymbol{\nabla}$ springeropen.com 